\title{
An Investigation into the Iranian EFL Language Learners' Attitudes on TOEFL iBT
}

\author{
KAMAL HEIDARI SOURESHJANI, PARISA RIAHIPOUR \& AREZOO SAFIKHANI \\ Islamic Azad University, Shahrekord Branch, Iran
}

\begin{abstract}
Bio Data:
Kamal Heidari Soureshjani holds M.A in TEFL from Shiraz University and is a Young Researchers Club Member. He taught English courses and IELTS at different institutes in Shiraz and is presently the academic member of Azad University, Shahrekord branch.
\end{abstract}

Parisa Riahipour has M.A. in TEFL and is now an instructor in Islamic Azad university, Shahrekord Branch. She has been teaching English in different institutes and in different levels for about three years.

Arezoo Safikhani also has M.A. in TEFL and has been teaching English in different institutes and in different levels for several years. She has compiled a set of articles published in different journals.

\begin{abstract}
The present study, which was probably the first of its kind in Iran, aimed at investigating the attitudes of Iranian iBT candidates towards the iBT test. It especially addressed the role of gender in the attitude of the participants of the study on iBT test. Accordingly, an attitude questionnaire was developed based on the theoretical framework of the study and then administered among Iranian iBT candidates who had taken the test in Shiraz, Iran. The collected data was then analyzed through chi-square and T-test to see if there was any meaningful relationship between candidates' sex and their attitudes towards the iBT test. The study revealed that first, most of the participants in the study had a positive attitude toward iBT and second, it was found out that the candidates' gender had no significant role in their attitudes towards iBT test. Implications can be drawn for all the stakeholders including candidates intending to sit for the test, institutes running iBT preparation program and teachers wishing to teach such programs.
\end{abstract}

Key terms: iBT test, t-test, Iranian candidates' attitudes

\section{Introduction}

The Test of English as a Foreign Language Internet-Based test (TOEFL iBT) was designed as a measure of English ability for university academic studies in North America. It was introduced in September 2005 and gradually spread worldwide during 2005 and 2006. TOEFL iBT was developed in response to a request by 
institutions that would measure non-native speakers' ability to communicate in English in an academic setting. iBT which is a $100 \%$ academically-focused test, meaning that it measures the kind of English language used in academic settings, specifically has been designed to measure the ability to communicate by combining, or integrating, all four language skills.

The concept of attitude has been the focus of attention in explanation of human behavior offered by social psychologists. Attitude is usually defined as a disposition or tendency to respond positively or negatively towards a certain thing such as an idea, object, person or situation. Students may have positive or negative attitudes towards the language they want to learn or the people who speak it. Having positive attitudes is claimed to be one of the reasons which make students perform better.

\section{Literature Review}

\section{History of TOEFL}

The Test of English as a Foreign Language, better known as TOEFL, is designated to measure the English language proficiency of people whose native language is not English. TOEFL scores are accepted by more than 6000 colleges, universities, and licensing agencies in 130 countries. The test is also used by governments, and scholarship and exchange program worldwide. A list of institutions and agencies that accept TOEFL scores is available on the TOEFL website at www.ets.org/toefl.

A national council on the testing of English as a foreign language was formed in 1962; its members were representatives of more than 30 private organizations and government agencies concerned with the English language proficiency of nonnative speakers of English who wished to study at colleges and universities in the United States. The council supported the development of the TOEFL test for use starting in 1963-64. Financed by grants from the Ford and Dan Forth Foundations, the TOEFL program was first administered by the Modern Language Association. In 1965, the College Board and Educational Testing Service (ETS) assumed joint responsibility for the program. Because many who take the TOEFL test are potential graduate students, a cooperative arrangement for the operation of the test was entered into by ETS, The College Board, and the Graduate Record Examinations Board in 1973. Under this arrangement, ETS is responsible for administering the TOEFL program with guidance from the TOEFL Board.

The test originally contained five sections. As a result of extensive research, a three-section test was developed and introduced in 1976. In July 1995, the test item format was modified somewhat within the same three-section structure. In recent years, various constituencies called for a new TOEFL test that 1) be more reflective of communicative competence models; 2) include more constructed-response tasks and direct measures of writing and speaking; 3 ) include tasks that integrate the language modalities tested; and 4) provide more information than the paper-based TOEFL test (TOEFL PBT) about the ability of international students to use English in an academic environment. Accordingly, the TOEFL Board initiated a board effort under which language testing will evolve in the twenty-first century. The introduction of the computer-based TOEFL test (in TOEFL CBT) 1998 was the first incremental step in this broad test-improvement effort. 
The next step was the introduction of an Internet-based TOEFL test (TOEFL iBT) in September 2005. The test was first launched in the United States, and gradually rolled out worldwide during 2005 and 2006. TOEFL iBT assesses all four language skills (reading, listening, speaking and writing) that are important for effective communication. TOEFL iBT emphasized integrated skills and provides better information to institutions about students' ability to communicate in an academic setting and their readiness for academic coursework.

As TOEFL iBT was introduced in an area, TOEFL CBT was discontinued after a period of overlap to insure a smooth transition to TOEFL iBT. The final administration of TOEFL CBT was held in September 2006. TOEFL PBT will continue to be offered on a limited basis to support the TOEFL testing network in areas where TOEFL iBT is not available.

\section{Attitude}

The concept of attitude has been the focus of attention in explanation of human behavior offered by social psychologists. Johnson \& Johnson (1998) define attitudes as opinions, beliefs, ways of responding, with respect to some sets of problems. So, they contain or closely relate to our opinion, belief and are based on our experiences. Attitudes represent a major connection between cognitive and social psychology since they are often related to interaction with others. They are strongly connected to feelings. According to Lange \& James (1972), attitudes suggest a feeling for or against something. Ajzan (1988) believes that they are latent hypothetical characteristics that can be inferred from external \& observable cues. Sarnoff (1970) has also defined attitude as a disposition to react favorably or unfavorably to an object, situation, person or event.

Attitudes, like other aspects of the development of cognitive \& affective factors in human being, develop early in childhood and are the result of parents' \& peers' attitudes of contact with people who are different in any number of ways and of interacting affective factors in human experience. Thus attitudes form a part of one's perception of self of others, and of the culture in which they are living (Brown, 2000).

\section{Attitudes toward Language, Language Learning and Language Tests}

Gardner and Lambert (1972) believe that attitudes toward language are defined in terms of different orientations towards language learning. Major orientations are called integrative and instrumental orientations. According to Oxford \& Shearin (1994) attitude is one of the factors impacting motivation in language learning.

Attitudes that have been explored in relation to language learning range from anxiety about language and the learning situation, through attitudes to speakers of the second language, the country in which it is spoken, the classroom, the teacher, other learners, the nature of language learning, particular elements in the learning activities, tests and beliefs about learning in general (Johnson \& Johnson, 1998). Chastain (1998) regards attitude as one of the variables contributing to second language learning. Besides, attitudes can be positive/negative. Bachmann (1976) has argued that high achievement causes positive attitudes and high motivation. 
Mantle (1995) examined the language and culture attitudes of middle schools participating in a foreign language exploratory program. Results clearly revealed that many students enter their first language class with misconception about language learning that may hinder their progress or persistence in language study.

A host of studies have also investigated the relationship between attitudes and proficiency levels. Gardner (1985) as an example believes that attitudes and other affective variables are as important as aptitude for language achievement. A study carried out by Krajewska (1997) also showed a positive relationship between attitude \& language abilities. Malallaha (2000) investigated the attitudes of Arab learners toward English and discovered that they have positive attitudes toward the English language and their proficiency in tests was positively related to their positive attitudes toward English.

On the whole, one can claim that having positive/negative attitudes towards a certain language can exert considerable effect on the learners' performance on a language test. By the same token, learners' attitudes toward a certain language proficiency test may affect their performance on their test. iBT candidates' attitudes towards iBT, therefore, might affect their overall score they get in this standardized test.

\section{Significance of the Study}

To the best of researchers' knowledge, no similar study has been done in the EFL context of Iran. In this perspective, therefore, the present study hopes to gain significance as the results can help all iBT -TOEFL stakeholders including candidates intending to participate in the test, institutes holding preparation program for iBT, teachers wishing to teach such programs and finally iBT test administrators who are running the test in Iran. The iBT venues must be undergone quality control processes more often and iBT administrators, ushers and examiners must be trained regularly so that everything goes well and in a standard fashion.

\section{Objectives of the Study}

The main objective of this study is to determine the attitudes of Iranian candidates towards the TOEFL iBT test. In addition, factors such as test environment, test rubric, candidates' age and sex and their relationship with candidates' attitudes will be investigated. The study therefore, seeks answers to the following questions:

1) What do Iranian candidates think of the TOEFL iBT test?

2) Does the gender of participants make a distinction in their attitudes?

\section{Method}

\section{Participants}

The study was conducted with the participation of two independent groups of participants. The first group consisted of 150 Iranian iBT candidates who took the actual test in Shiraz University. All of them were from Iran and speak Farsi as their first language. They were 69 male and 81 female candidates ranging from 22 to 54 in age. They were also from different educational backgrounds. As to the second group of participants, 25 of the candidates apart from the first group, were randomly 
picked out and interviewed. They were also both male and female (10 male and 15 female) and aged from 24 to 46 with different educational backgrounds.

\section{Instruments}

A questionnaire and an interview were employed in the study to gather the required data from the participants. As to the questionnaire, it was an attitude questionnaire (see appendix 1) developed by addressing the overall attitudes of the candidates towards iBT test based on the theoretical framework adopted for the study. The main purpose of the questionnaire distribution among the participants was to address the overall attitude of the candidate towards iBT and their attitudes towards the four component of the iBT test, i.e. listening, reading, writing and speaking. Finally, its reliability was estimated through Cronbach Alpha which yielded 0.75 and its validity was determined through being examined and confirmed by some related professors.

After taking the test by the participants, 25 of the candidates were randomly selected for the second instrument of the study that is, a semi-structured interview (See Appendix 2). The items of the questionnaire were in keeping with the items of the attitude questionnaire so that, the participants' responses would be more consistent. The point with regard to the participants who took the interview is that they were apart from the ones who filled in the attitude questionnaire.

\section{Data Collection}

In order to collect the data, one of the researchers of the study first distributed the questionnaire among the candidates and asked them to fill it in carefully. They were seated at a previously-prepared room with enough time for the filling out the forms.

As to the interview, the other researcher of the study asked some of the participants to do an interview about the test. From among about 50 candidates, just 25 of them agreed to be interviewed. Again, for the interview there was previously prepared a suitable and comfortable place so that the interviewees were able to feel relaxed and answer the questions in an ideal condition.

\section{Data Analysis}

To analyze the gathered data, two different methods of analysis were used. As to the questionnaire, in order to get knowledge with regard to the participants' perspectives about the iBT test, a chi-square was run. Then in order to ascertain whether or not the gender of participants has any impact on their attitudes a t-test was run. With regard to the interview results, the responses of the participants were described, analyzed, and compared with the questionnaire results.

\section{Results and Conclusion}

Having conducted the study and gathered the required data, now in this section of the study the main results of the study are presented. To do so, the research questions of the study are presented one by one and then their answers based on the study findings are mentioned.

1) What do Iranian candidates think of the TOEFL iBT test?

The first research question of the study seeks the attitude of the candidates apropos of the iBT test. Table 1 which represents the attitude of the candidates in terms of 


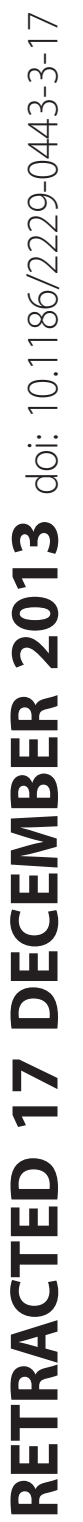


the candidates' responses. The table, in keeping with table 1, manifests that both males and females responded positively to the items of the questionnaire.

Table 2

Gender and Attitude Crosstabulation

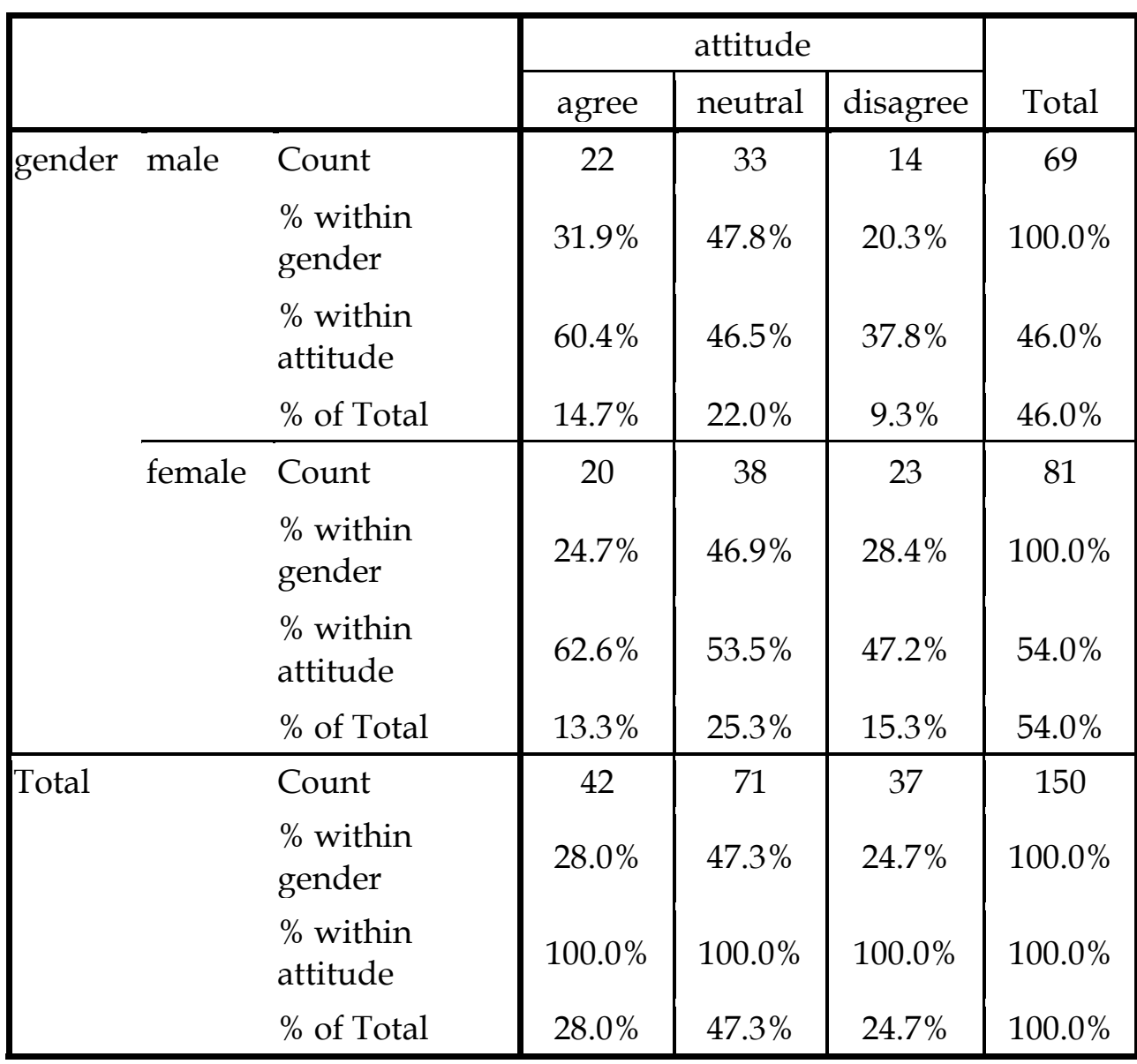

In addition, table 3 labeled as chi-square tests reveals that since the reported Sig. value is larger than $.05(p=.43)$ therefore, the male and female candidates do not differ from each other in terms of their attitudes towards iBT test.

Table 3

Chi-Square Tests 


\begin{tabular}{|l|c|c|c|}
\hline & Value & df & $\begin{array}{c}\text { Asymp. Sig. } \\
\text { (2-sided) }\end{array}$ \\
\hline Pearson Chi-Square & $1.687 \mathrm{a}$ & 2 & .430 \\
Likelihood Ratio & 1.698 & 2 & .428 \\
Linear-by-Linear & 1.648 & 1 & .199 \\
Association & 150 & & \\
N of Valid Cases & & \\
\hline
\end{tabular}

a. 0 cells $(.0 \%)$ have expected count less than 5 . The minimum expected count is 17.02 .

As to the interview results pertaining to this research question, most of the interviewees thought positively with regard to the iBT test. As an example, one of them stated that:

I have previously taken different forms of TOEFL whether paper-based or computerbased versions. Now that I took the iBT form too, I personally think that this form of test was much better than the other two forms in different terms such as the procedure of test taking, the time allocation, and also the preparatory actions like its enrolment.

This candidate has the advantage of taking all other types of TOEFL. Therefore, her responses can be a good judge. She said that one of the advantages of iBT over other forms of the test is the procedure of test taking. That is, instead of sitting for a long time in our seats waiting for the proctors to bring the papers (as in paper-based form) and also using traditional stationery such as pen, pencil, eraser, etc. in the iBT form, we don't need any pen and pencil (just for some times like taking a note), we can easily access the questions on the net. The point needs to be noticed here is that although this kind of test-taking may be easier and more comfortable than the traditional forms, there are, however, some people who may not be able to work with modern equipments. In line with this point, one of the interviewers asserted that:

I had really studied for the test. Before I took the test I was certain that I will get an excellent score on the test. But when I started taking the test, I didn't know how to work with the machine. I got so nervous as the test starts. I couldn't use my knowledge on the test just due to lack of familiarity with the computer.

This statement easily points to the point that although technology-based test taking can be a great help in the more effective, practical, and efficient test taking, it can also be a disaster for some. That is, there were some candidates who had problems like lack of familiarity with the used technology, lack of sufficient knowledge with regard to the format of the test, etc. Another candidate who was interviewed remarked that:

I think personally that iBT test was, all in all, better and more standardized in comparison to the other formats. However, there are still some problems. As an 
example, I believe that with regard to the reading section of the test, there wasn't a balance between the length of texts, the included items and the allocated time. To put clearly, the length of texts followed by its related questions was my main difficulty with the test. I couldn't answer most of the items just due to lack of sufficient time.

Some of the interviewed candidates positively agreed that iBT test was by far more stress free than the previous formats. One of them, for instance, added that:

IBT test was really more standard than the previous formats. The main reason for this claim is that it is less threatening for the candidates. To my own experience, when I sat for the test I was somehow nervous initially but immediately after starting the test I was downright relaxed. I didn't have to wait for the proctors to distribute the papers and to announce the instructions loudly. I worked on my own pace and I felt no pressure on me.

2) Does the gender of participants make a distinction in their attitudes?

Regarding the second research question about the effect of gender on the candidates' attitudes towards the iBT test, the results of t-test signaled no significant result. In other words, as it is conspicuous from table 4, there is no significant relationship between the gender of candidates and their attitudes (Sig. $=.20>.05$ ).

Table 4

Independent Samples Test

\begin{tabular}{|c|c|c|c|c|c|c|c|c|c|}
\hline & \multicolumn{2}{|c|}{$\begin{array}{l}\text { Levene's } \\
\text { Test for } \\
\text { Equality of } \\
\text { Variances }\end{array}$} & \multicolumn{7}{|c|}{ t-test for Equality of Means } \\
\hline & \multirow[b]{2}{*}{$\mathrm{F}$} & \multirow[b]{2}{*}{ Sig. } & \multirow[b]{2}{*}{$t$} & \multirow[b]{2}{*}{$\mathrm{df}$} & \multirow{2}{*}{$\begin{array}{l}\text { Sig. (2- } \\
\text { tailed) }\end{array}$} & \multirow{2}{*}{$\begin{array}{c}\text { Mean } \\
\text { Difference }\end{array}$} & \multirow{2}{*}{$\begin{array}{l}\text { Std. Error } \\
\text { Difference }\end{array}$} & \multicolumn{2}{|c|}{$\begin{array}{c}95 \% \text { Confidence } \\
\text { Interval of the } \\
\text { Difference }\end{array}$} \\
\hline & & & & & & & & Lower & Upper \\
\hline $\begin{array}{l}\text { attitude Equal } \\
\text { variances } \\
\text { assumed }\end{array}$ & .049 & .82 & $\begin{array}{l}- \\
1.2\end{array}$ & 148 & .20 & -.15 & .11 & -.38 & .081 \\
\hline $\begin{array}{l}\text { Equal } \\
\text { variances } \\
\text { not } \\
\text { assumed }\end{array}$ & & & - & 145.062 & .20 & -.15 & .11 & -.38 & .081 \\
\hline
\end{tabular}

Although no significant difference was observed between the male and female candidate in their attitudes about iBT test, table 5 shows that, by exploring the Mean and SD values, the female candidates were more consistent and similar in their attitudes in comparison to the male candidates' attitudes.

Table 5 
Group Statistics of Gender and Attitudes

\begin{tabular}{|ll|c|c|c|c|}
\hline & gender & $\mathrm{N}$ & Mean & $\begin{array}{c}\text { Std. } \\
\text { Deviation }\end{array}$ & $\begin{array}{c}\text { Std. Error } \\
\text { Mean }\end{array}$ \\
\hline attitud & male & 69 & 1.8 & .73 & .08 \\
e & female & 81 & 2.0 & .71 & .08 \\
\hline
\end{tabular}

\section{Conclusion}

The present study was, in fact, an attempt to investigate the Iranian candidates' attitudes towards iBT test. It also examined the role of gender in their attitudes. To put it another way, the paper tried to cast light on this point that whether or not male and female iBT candidates differ in their attitudes towards the test. To achieve these purposes, 150 male and female Iranian iBT test candidates were selected and then a developed questionnaire was given to them to fill it in. Besides, 25 more candidates were also interviewed to gather their views about the test.

The study results revealed that most of the Iranian candidates looked positively at the iBT test. It was also found out that the gender of candidates has no significant role in their attitudes toward the test. In other words, the study showed that male and female candidates don't differ significantly in terms of their views about iBT test.

Implications can be drawn for all iBT stakeholders, those who intend to sit for $\mathrm{iBT}$, those who run iBT preparation programs, and also those who develop the questions and administer the iBT test. Those in charge of administration of iBT in Iran should pay proper attention to the demands of Iranian candidates while taking the test. Equipping all the iBT centers with some facilities such as headphones for the listening section of iBT seems to be essential. Participants of this study viewed physical conditions of iBT such as light, temperature and chairs highly effective on their performance on the test and thus their attitude towards iBT. Test makers can also benefit from the findings of this study. They might decide to modify the listening section in a way so that it will reduce the stress and confusion of candidates who are not familiar with the format of the test. They might also increase the time limit for the reading section or also truncate the length of passages. Finally, those in charge of running iBT preparation programs can also take advantage of this and similar studies in that based on studies carried out on the same issue, listening and reading are the most difficult sections of iBT test. They should provide candidates with many authentic texts and encourage them to read extensively outside the classroom.

The study, despite the author's efforts, suffers from a set of limitations. First of all, the number of participants of the study was small, and the study was also limited to a single context hence, generalizing the study results may not be done with an absolute certainty. Consequently, in order to reach much more reliable findings further studies should be done with more participants from different Iranian contexts. Secondly, there may be some problems with regard to the instruments of the study especially the questionnaire. Some more items may need to be added to the questionnaire. 
Further studies can be carried out to investigate issues related to iBT in Iran. Studies can be done involving the iBT listening and reading sections. Further studies can be run on the use of iBT for professional purposes or for migration. Studies on test preparation practices and investigation of the cognitive processes of iBT test takers can be done as well. Finally, studies can also be conducted investigating the relationship between candidates' stress and its effect on their performance on the test. 


\section{Reference}

Ajzan, I. (1988): Attitudes, personality, \& behavior. Stratford: Open University Press. Bachman, N. (1976). Two measures of affective factors as they relate to progress on adult second language learning. Working Papers on Bilingualism, 10, 100-122.

Brown, D. H. (2000). Principles of language learning and teaching (4th ed.). White Plains, NY: Pearson Education.

Chastain, K. (1998). Developing second language skills (2 ${ }^{\text {nd }}$ ed.). Chicago: Rand Macually Press.

Gardner, R. C., \& Lambert, W. E. (1972). Attitudes and motivations in second language learning. Rowley, MA: Newbury House Publishers.

Gardner, R. C. (1985). Social psychology and second language learning. London: Edward Arnold.

Johnson, K., \& Johnson, H. (1998). Encyclopedic dictionary of applied linguistics. Oxford: Blackwell Publishers Ltd.

Krajewska, U. (1997). Second language learning and the attitudes about foreigners. Jezki-obce-w-szkole, 41, 407-411.

Lange, D. C., \& James, C. J. (1972). Foreign language education: Reappraised. Shokie, Illinois: National textbook company.

Malallaha, S. (2000). English in Arabic environment: Current attitudes to English among Kuwait University Students. International Journal of Bilingual Educations $\mathcal{E}$ Bilingualism, 3, 19-43.

Mantle-Bromley, C. (1995). Positive attitudes and realistic beliefs: Links to proficiency. Modern Language Journal, 79(3), 372-386.

Oxford, R., \& Shearin, J. (1994). Language learning motivation: Expanding the theoretical framework. Modern Language Journal, 78, 12-28.

Sarnoff, I. (1970). Social attitudes and the resolution of motivational conflict. Harmondsworth: Penguin.

\section{Appendix 1}

\section{Dear participants:}

Please read the following items and then select the choice which is more consistent with your perspectives. It is worth mentioning that your choices are just for the purpose of research and the results will be kept confidential.

Gender: Male $\square \quad$ Female $\square$

Age:

\section{Educational Background:}

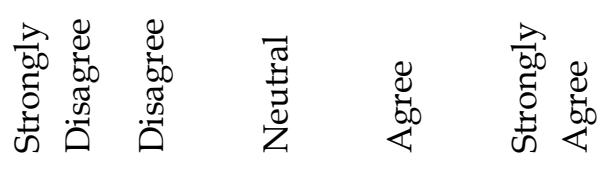

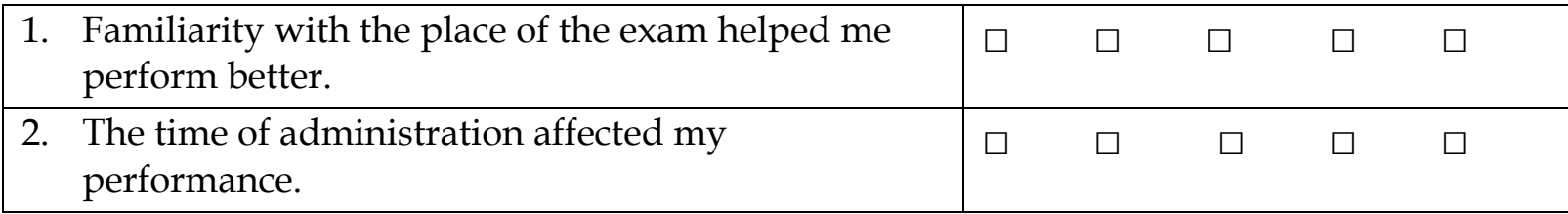




\begin{tabular}{|c|c|c|c|c|c|}
\hline $\begin{array}{l}\text { 3. The physical conditions such as light, temperature, } \\
\text { chairs affected my performance. }\end{array}$ & $\square$ & $\square$ & $\square$ & $\square$ & $\square$ \\
\hline $\begin{array}{l}\text { 4. Lack of familiarity with computer use affected my } \\
\text { performance negatively. }\end{array}$ & $\square$ & $\square$ & $\square$ & $\square$ & $\square$ \\
\hline 5. Fear of the test affected my performance. & $\square$ & $\square$ & $\square$ & $\square$ & $\square$ \\
\hline $\begin{array}{l}\text { 6. Familiarity with the test format \& rubric helped me } \\
\text { perform better. }\end{array}$ & $\square$ & $\square$ & $\square$ & $\square$ & $\square$ \\
\hline 7. I prefer iBT to other English proficiency tests. & $\square$ & $\square$ & $\square$ & $\square$ & $\square$ \\
\hline $\begin{array}{l}\text { 8. It is a proficiency test \& doesn't evaluate other } \\
\text { competencies. }\end{array}$ & $\square$ & $\square$ & $\square$ & $\square$ & $\square$ \\
\hline $\begin{array}{l}\text { 9. Time was a significant factor regarding my } \\
\text { performance. }\end{array}$ & $\square$ & $\square$ & $\square$ & $\square$ & $\square$ \\
\hline 10. Listening is the most difficult section of iBT. & $\square$ & $\square$ & $\square$ & $\square$ & $\square$ \\
\hline $\begin{array}{l}\text { 11. Lack of familiarity with British/Australian accents } \\
\text { affected my performance adversely. }\end{array}$ & $\square$ & $\square$ & $\square$ & $\square$ & $\square$ \\
\hline $\begin{array}{l}\text { 12. They speak very fast in the speaking sections of the } \\
\text { test. }\end{array}$ & $\square$ & $\square$ & $\square$ & $\square$ & $\square$ \\
\hline 13. The quality of voice affected my performance. & $\square$ & $\square$ & $\square$ & $\square$ & $\square$ \\
\hline 14. Wearing headphones helped me to perform better. & $\square$ & $\square$ & $\square$ & $\square$ & $\square$ \\
\hline $\begin{array}{l}\text { 15. The reason why I missed some of the questions was } \\
\text { that I had to answer while listening. }\end{array}$ & $\square$ & $\square$ & $\square$ & $\square$ & $\square$ \\
\hline 16. Listening became harder section by section. & $\square$ & $\square$ & $\square$ & $\square$ & $\square$ \\
\hline $\begin{array}{l}\text { 17. Having to answer a variety of questions distracted } \\
\text { me. }\end{array}$ & $\square$ & $\square$ & $\square$ & $\square$ & $\square$ \\
\hline $\begin{array}{l}\text { 18. The Listening section tended to evaluate my } \\
\text { knowledge of vocabulary \& speed of typing rather } \\
\text { than my listening comprehension. }\end{array}$ & $\square$ & $\square$ & $\square$ & $\square$ & $\square$ \\
\hline $\begin{array}{l}\text { 19. Fear of listening affected my performance } \\
\text { adversely. }\end{array}$ & $\square$ & $\square$ & $\square$ & $\square$ & $\square$ \\
\hline $\begin{array}{l}\text { 20. Listening to English programs made me perform } \\
\text { better on listening section. }\end{array}$ & $\square$ & $\square$ & $\square$ & $\square$ & $\square$ \\
\hline $\begin{array}{l}\text { 21. Command of vocabulary not helped me to perform } \\
\text { better. }\end{array}$ & $\square$ & $\square$ & $\square$ & $\square$ & $\square$ \\
\hline 22. Reading is the most difficult section of iBT. & $\square$ & $\square$ & $\square$ & $\square$ & $\square$ \\
\hline $\begin{array}{l}\text { 23. The fact that I had to answer reading questions after } \\
\text { listening affected my performance. }\end{array}$ & $\square$ & $\square$ & $\square$ & $\square$ & $\square$ \\
\hline $\begin{array}{l}\text { 24. The variety of questions in the reading section } \\
\text { distracted me. }\end{array}$ & $\square$ & $\square$ & $\square$ & $\square$ & $\square$ \\
\hline
\end{tabular}




\begin{tabular}{|c|c|c|c|c|c|}
\hline 25. Lengthy texts helped me locate the answers easily. & $\square$ & $\square$ & $\square$ & $\square$ & $\square$ \\
\hline 26. Lengthy texts made me exhausted. & $\square$ & $\square$ & $\square$ & $\square$ & $\square$ \\
\hline 27. One hour is sufficient to answer all the questions. & $\square$ & $\square$ & $\square$ & $\square$ & $\square$ \\
\hline $\begin{array}{l}\text { 28. Texts became more difficult toward the end of the } \\
\text { section }\end{array}$ & $\square$ & $\square$ & $\square$ & $\square$ & $\square$ \\
\hline $\begin{array}{l}\text { 29. Good command of vocabulary items helped me } \\
\text { perform better. }\end{array}$ & $\square$ & $\square$ & $\square$ & $\square$ & $\square$ \\
\hline $\begin{array}{l}\text { 30. Good command of grammar structures helped me } \\
\text { perform better. }\end{array}$ & $\square$ & $\square$ & $\square$ & $\square$ & $\square$ \\
\hline $\begin{array}{l}\text { 31. The vocabulary list option helped me perform } \\
\text { better. }\end{array}$ & $\square$ & $\square$ & $\square$ & $\square$ & $\square$ \\
\hline $\begin{array}{l}\text { 32. Reading a lot of texts before exam helped me } \\
\text { perform this section better. }\end{array}$ & $\square$ & $\square$ & $\square$ & $\square$ & $\square$ \\
\hline 33. Writing is the most difficult part of the exam. & $\square$ & $\square$ & $\square$ & $\square$ & $\square$ \\
\hline $\begin{array}{l}\text { 34. Lack of familiarity with typing affected my } \\
\text { performance. }\end{array}$ & $\square$ & $\square$ & $\square$ & $\square$ & $\square$ \\
\hline $\begin{array}{l}\text { 35. I was tired because of performance on two other } \\
\text { sections. }\end{array}$ & $\square$ & $\square$ & $\square$ & $\square$ & $\square$ \\
\hline 36. Lengthy topics distracted me. & $\square$ & $\square$ & $\square$ & $\square$ & $\square$ \\
\hline $\begin{array}{l}\text { 37. Knowledge of vocabulary\& grammar helped me in } \\
\text { this section. }\end{array}$ & $\square$ & $\square$ & $\square$ & $\square$ & $\square$ \\
\hline $\begin{array}{l}\text { 38. Not having enough information on the given topic } \\
\text { was my main problem. }\end{array}$ & $\square$ & $\square$ & $\square$ & $\square$ & $\square$ \\
\hline $\begin{array}{l}\text { 39. Having practiced a lot before the exam helped me } \\
\text { perform better \& faster. }\end{array}$ & $\square$ & $\square$ & $\square$ & $\square$ & $\square$ \\
\hline 40. Knowledge of essay writing helped me write better. & $\square$ & $\square$ & $\square$ & $\square$ & $\square$ \\
\hline $\begin{array}{l}\text { 41. The integrated \& independent parts were different } \\
\text { in terms of difficulty. }\end{array}$ & $\square$ & $\square$ & $\square$ & $\square$ & $\square$ \\
\hline 42. Speaking is the most difficult section of the iBT. & $\square$ & $\square$ & $\square$ & $\square$ & $\square$ \\
\hline $\begin{array}{l}\text { 43. The interview section tests one's listening ability } \\
\text { rather than speaking one. }\end{array}$ & $\square$ & $\square$ & $\square$ & $\square$ & $\square$ \\
\hline 44. Stress was my main problem in this section. & $\square$ & $\square$ & $\square$ & $\square$ & $\square$ \\
\hline 45. I had self-confidence at the beginning of the section. & $\square$ & $\square$ & $\square$ & $\square$ & $\square$ \\
\hline $\begin{array}{l}\text { 46. Allocated time was a fair criterion based on which } \\
\text { my speaking ability be assessed. }\end{array}$ & $\square$ & $\square$ & $\square$ & $\square$ & $\square$ \\
\hline
\end{tabular}


47. Living in Iran \& have a little opportunity to use the language affected my performance.

48. The integrated \& independent tasks were different in difficulty level.

\section{Appendix 2}

\section{The Interview Items}

What is your overall attitude towards iBT?

What is your attitude toward the listening section?

What is your attitude toward the reading section?

What is your attitude toward the writing section?

What is your attitude toward the speaking section?

What factors affect your performance adversely?

What are the advantages of iBT over the paper-based and computer-based versions of TOEFL test?

If you want to add anything to your remarks please mention it. 